УДК $81 ’ 373.232 .1$

doi 10.17072/2037-6681-2018-2-122-126

\title{
ВЕРШИНИНА ИЗ ВЕРШИНИНО
}

\section{Татьяна Александровна Сироткина}

д. филол. н., доцент кафедры филологического образования и журналистики Сургутский государственный педагогический университет

628417, Россия, г. Сургут, ул. 50 лет ВЛКСМ, 10/2. sirotkina71@mail.ru

SPIN-код: 7901-7167

ORCID: http://orcid.org/0000-0003-3494-0968

ResearcherID: D-5802-2018

Статья поступила в редакичию 15.02.2018

Просьба ссылаться на эту статью в русскоязычных источниках следующим образом:

Сироткина Т. А. Вершинина из Вершинино // Вестник Пермского университета. Российская и зарубежная филология. 2018. Т. 10, вып. 2. С. 122-126. doi 10.17072/2037-6681-2018-2-122-126

Please cite this article in English as:

Sirotkina T. A. Vershinina iz Vershinino [Vershinina from Vershinino]. Vestnik Permskogo universiteta. Rossiyskaya $i$ zarubezhnaya filologiya [Perm University Herald. Russian and Foreign Philology], 2018, vol. 10, issue 2, pp. $122-126$. doi 10.17072/2037-6681-2018-2-122-126 (In Russ.)

Дается представление об одном из новых лексикографических изданий ученых томской лингвистической школы - «Идиолектном ономастиконе сибирского старожила» (авт.-сост. Е. В. Иванцова, Е. А. Берестова; под ред. Е. В. Иванцовой. Томск: Изд-во Томского университета, 2015. 308 с.). Отмечается, что ономастикон рядового носителя языка до сих пор не был предметом словарного описания и словарь, созданный языковедами томской лингвистической школы, заполняет эту лакуну, положив начало традиции фиксации в отдельном издании разных типов собственных имен, функционирующих в речи диалектоносителя. Рецензентом прослеживаются основные принципы построения данного словаря. В продолжение традиций «Полного словаря диалектной языковой личности» ономастический словарь строится с учетом тех же методологических принципов: установка на максимальную полноту отражения лексикона языковой личности, ориентация на разноаспектное описание единиц лексикона, принцип объективации в словаре черт языковой личности носителя языка, принцип «мягкой» подачи пограничных явлений с одновременным отнесением спорных или смежных случаев в разные классы. Приводится характеристика иллюстративного материала, обладающего особой ценностью для читателей и представляющего собой объемную «энциклопедию» жизни русской деревни, ее будней и праздников. Выделяются также заслуживающие внимания маркированные особым знаком высказывания, которые содержат проявления метязыковой рефлексии говорящего в отношении имен собственных. В таких примерах объектом осмысления являются форма, семантика или функционирование имени собственного в своей или чужой речи: его благозвучие / неблагозвучие, его необычность, несоответствие официальному именованию, наличие вариантных обозначений, преимущественное употребление той или иной формы имени, мотив называния, коннотация онима, частотность, соблюдение / несоблюдение нормы употребления и т. д. На основании описания данного лексикографического издания сделан вывод о перспективах создания подобных словарей на диалектном материале других территорий России.

Ключевые слова: идиолектный ономастикон; лексикография; томская лингвистическая школа; словарь; оним.

(C) Сироткина Т. А., 2018 
В современной русской лексикографической практике особое место принадлежит словарям идиолектной онимии. Однако даже в более разработанной «авторской лексикографии» (термин Л. Л. Шестаковой) словарей, отражающих идиолекты писателей, пока совсем немного. К ним можно отнести словарь имен собственных, функционирующих в произведениях петербургского периода А. С. Пушкина [Обухова 2009], ономастикон поэм М. Ю. Лермонтова [Гильбурд 2006]. Часть антропонимов и топонимов включена в Словарь языка А. С. Пушкина (отдельного словаря имен собственных произведений поэта пока нет). Онимы даны как приложение к Словарю языка русских произведений Т. Г. Шевченко [Словарь 1985] (имена собственные даны списком в приложении № 4).

Как можно видеть, все они полного представления об идиолектном ономастиконе личности не дают: в приложении к словарю Т. Г. Шевченко нет контекстов, помет; в словаре А. М. Гильбурда материал ограничен поэмами М. Ю. Лермонтова, в словаре Е. С. Обуховой - одним из периодов творчества А. С. Пушкина.

Ономастикон рядового носителя языка до сих пор не был предметом словарного описания. Словарь, созданный языковедами томской лингвистической школы, заполняет эту лакуну, положив (хочется надеяться) начало традиции фиксации в отдельном издании разных типов собственных имен, функционирующих в речи диалектоносителя.

Источником «Идиолектного ономастикона...» послужили записи речи жительницы села Вершинино Томской области Веры Прокофьевны Вершининой, 1909 года рождения, в условиях непринужденного общения с родственниками, односельчанами, знакомыми и диалектологами, также воспринимавшимися информантом в качестве близких людей. Как отмечают авторы словаря, «материал систематически собирался методом включения в языковое существование говорящего в течение 24 лет (57 экспедиционных выездов с 1981 по 2004 г.).

«Ономастикон...» - часть лексикографической серии, посвященной словарному представлению идиолекта сибирской крестьянки. В серию входят базовый толковый «Полный словарь диалектной языковой личности» [Полный... 20062012] в 4 томах и ряд аспектных: словарь сравнений [Иванцова 2005], ономастикон [Идиолектный... 2015] и словарь прецедентных текстов [Иванцова 2016]. В данный момент идет работа над идеографическим словарем (авт.-сост. С. С. Земичева), есть также планы создания синонимо-антонимического словаря.
С учетом традиций «Полного словаря диалектной языковой личности» ономастический словарь строится на тех же методологических принципах: установка на максимальную полноту отражения лексикона языковой личности, ориентация на разноаспектное описание единиц лексикона, принцип объективации в словаре черт языковой личности носителя языка, принцип «мягкой» подачи пограничных явлений с одновременным отнесением спорных или смежных случаев в разные классы. Последний из них позволил «включить в новый словарь единицы, занимающие промежуточное положение между именами собственными и нарицательными» (с. 8).

Поставленная составителями цель словаря «представление идиолектной системы имен собственных как значимой составляющей лексикона языковой личности» (с. 4) - достигнута в полной мере. Ономастикон сибирского старожила предстает перед читателем как единая, целостная языковая система, отражающая традиции именования жителей, моду на конкретные антропонимы, отношение информанта к тем или иным именам собственным. Всего в ономастиконе представлено «1500 онимов, зафиксированных в идиолекте носителя традиционной народноречевой культуры» (с. 10).

При построении словаря авторами было принято решение (с которым можно согласиться, а можно и поспорить) выделить в его структуре три части: часть 1 - «Антропонимы» (с. 11-201), часть 2 - «Топонимы» (c. 202-270), часть 3 «Прочие имена собственные», где отражены клички животных, наименования марок автомобилей и бытовой техники, учреждений, магазинов, названия радиопередач, песен и др. (с. 271303). Такой подход, казалось бы, разрушает целостность ономастического пространства носителя языка, однако на самом деле позволяет четко выстроить три подсистемы, обладающие внутренней логикой построения. Так, например, словарные статьи, посвященные именам людей, включают «сведения о звуковой оболочке лексикографируемого антропонима (или антропонимов, входящих в гнездо), его словоизменении, разряде данного онима, производных образованиях, семантических и функциональных особенностях лексемы» (с. 12); топонимы и прочие имена собственные по определению имеют менее разветвленную систему связей и отношений.

Сказанное выше можно продемонстрировать примерами словарных статей из разных частей словаря:

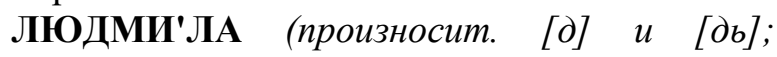
р. Людми'ле) - имя жен., полн. О 86. 
Раньше-то цясто были. Лю'дын муж тоже, Людмила мне племянница; Я говорю [односельчанке, живущей одной]: «Да ты не мину'ешь Раю. Не мину'ешь Раю. У Людьмиле своя семья вон кака', а тут никакой семьи нету»; Людьмила Гево'ргевна, вот бе'лы-то, жёлты эти карто'шкито у меня - вы садили, нет их?; Как у Людмиле Гео'ргевне родители там, ничё? Ба'ушка-то жива? Ли нет ли? Не говорила?; Раздевайся! Людмила Иванна.

Людми'лин. 1. «Мой-то [пёс] не укусит! А вот эта, Людмилина там [собака] - может укусить».

- Лю'да (р. Лю'де, д. Лю'ды) - неполн. О 213. Люда, выпей чашечку чаю!; Володя её [мать] забрал, к Люды привёз.

> Лю'dын. 13. А у это, у Коли, у Людыного, тёшша рабо'тат в больнице; А это... напро'ти Поли Каря'кины жили... Сара была - Гришина мать там, Людына мать была...

- Лю'дка - неполн. O 16. А эта, Людка ли однако была?; А я хотела платьишко надевать, да это... неудобно, при Людке-то; «Как не будешь то'лста! - она на меня. - Всё стря'пашь да варишь всегда». Я говорю: «Ну и чё?» - «Да! Мне тоже Людка [внучка] возит».

$>$ Лю'dкин. 1. Молоденький мальчишка «Я, гыт, не знаю, ра'зе Пашка [сын] Людки Райкиной?» - говорит. Я говорю: «Да ты чё? Он откэ'дова попадёт [сюда из села Ярское]? Людкин».

- Лю'дочка - квалит., ласк. O 1. [Корвалол пьёте?] Всё время пью, не перестаю. Како'-то... Людочка сказала, како'? Како'-то лекарство хотела купить мне, да и никого', я и деньги не дала, ничё.

- Лю'ся - неполн. $O$ 1. Ну ей всё равно Люся помога'т.

ДУДА'Й - прозв. от фам. Дудаев. ЧР. 2. $\square$ Джохар Дудаев - лидер чеченского движения 1990-х г2.

* Катя! А вот это... как его? о'споди... в Чечне-то. Куды' девался этот [Дудаев]? Гыт, «убили». А Рая дак Лёньку зовёт «Дудаем», гыт. Хо! «Дудай-то, гыт, чё!» [Какого?] От этого [указывает на дом соседа]. [Почему?] Не знаю, какой серьдитый он ли чё ли.

КАЗА'НКА. Деревня в Томской области, расположенная по трассе между Томском и Вериинино. 12.

А дом-то никого ешо не строят щас. Ну, лес возят, кто-то сказал мне вчера. То ли Таня, то ли Гутя. С Басандайки. Нет, с Казанки; Прода'с, а наза'втре опе'ть туды', по черёмуху по эту, на во'стров. Не на этот остров, а там, перед Кола'ровой... этой, Казанкой во'стров-то; Кода' больша' вода - до Казанки всё, и тут всё затопит; Они картошку хотели обрабатывать поехать окучивать, в Казанку; А он говорит: «А вам на Ярско'е надо?» - «Да, на Ярско'е». Он гыт: «Возьмите мне билет. До Казанки, гыт».

Каза'нский. Казанский остров. 1. [Этот остров никак не называется?] Остров, и всё, никак. Ну, Вершининскый остров так. А там Казанскый остров, дальше там. // Житель, уроженеи Казан$\kappa u$. 1. И я пи'вки ставила это, и банки ставила. [Здесь?] У-у. Я ставила, в городе, на это, на Татарской, татарка кака'-то ставила. А тя'те ставили - всё казански ездили, ходили ставили.

ЗАПОРО'ЖИЦА. Марка легкового автомобиля. < Запорожеи. 8 .

А у Гены машина-то но'ва, ему дали это как выделили фронтовику «запорожицу»; А машинёнка-то у его худа', купил каку'-то... «запорожицу», ну она нехоро'ша была.

Тщательно разработана и система функциональных помет рецензируемого словаря. Так, «К пометам об ограниченной сфере функционирования антропонима относятся «в чужой речи», «устаревающее», «новое» и «детское» (с. 16); «помета о неполной освоенности антропонима ставится, если контексты отражают наличие окказиональных вариантов, неуверенное или искаженное произношение имени собственного в речи информанта» (с. 17). Важным компонентом словарной статьи считаем и справочные сведения, особенно «данные о числе зафиксированных в текстах словоупотреблений» (с. 19) онимов.

Особой ценностью для читателей словаря, безусловно, обладает иллюстративный материал, представляющий собой объемную «энциклопедию» жизни русской деревни: ее будни и праздники («А сцяс вот Вознесенье быва'т, Христов день. Исус Христос спустился с неба» - с. 192), современность и историю («А кода'... Хрушшовто итобрали, тода'... совхоз-то начался, коров-то итобра'ли. В шеисят первом, наверно» - с. 193), местную топонимику («Бегали к Сухой речке, туды', где ко'нплекс - веночки вили да...» с. 254) и прецедентные имена («Хоро'ша дочь Аннушка, хвалит мать и ба'ушка» - с. 43).

Заслуживают внимания также маркированные в иллюстративной зоне особым знаком высказывания, содержащие проявления метязыковой рефлексии говорящего в отношении имен собственных. В таких примерах объектом осмысления являются форма, семантика или функционирование имени собственного в своей или чужой речи: его благозвучие / неблагозвучие, его необычность, несоответствие официальному именованию, наличие вариантных обозначений, 
преимущественное употребление той или иной формы имени, мотив называния, коннотация онима, частотность, соблюдение / несоблюдение нормы употребления и т. д.

Изданный словарь послужил источником комплексного описания системы антропонимов диалектной языковой личности в недавно защищенной кандидатской диссертации Е. А. Астафьевой (Берестовой) и является ценным источником для сопоставительных ономастических исследований, которые проводятся или будут проводиться российскими ономатологами. Поэтому хочется выразить огромную признательность редактору словаря, профессору Екатерине Вадимовне Иванцовой, за подвижнический труд по сбору диалектного материала, верность традициям отечественной ономастики, привлечение к лексикографической работе своих учеников и пожелать удачи на поприще создания новых лексикографических трудов и исследования диалектной речи.

\section{Список литературы}

Гильбурд $A$. М. Словарь собственных имен в поэмах М. Ю. Лермонтова. Сургут: СурГПУ, 2006. 88 c.

Идиолектныцй ономастикон сибирского старожила / авт.-сост. Е. В. Иванцова, Е. А. Берестова; под ред. Е. В. Иванцовой. Томск: Изд-во Том. ун-та, 2015. 308 с.

Иванцуова Е. В. Идиолектный словарь сравнений сибирского старожила. Томск: Изд-во Том. ун-та, 2005. 162 с.

Иванцуова E. В. Идиолектный словарь прецедентных текстов сибирского старожила. Томск: Изд-во Том. ун-та, 2016. 132 с.

Обухова E. C. Ономастика творчества А. С. Пушкина петербургского периода (18171820): словарь. Воронеж: Истоки, 2009. 168 с.

Полный словарь диалектной языковой личности / под ред. Е. В. Иванцовой. Томск: Изд-во Том. ун-та, 2006. Т. 1. А-3. 358 с.; 2007. Т. 2.
И-О. 338 с.; 2009. Т. 3. П-Р. 324 с.; 2012. Т. 4. С-Я. $366 \mathrm{c.}$

Словарь языка русских произведений Шевченко: в 2 т. / сост. В. М. Брицын и др. Киев: Наукова думка, 1985.

\section{References}

Gilburd A. M. Slovar' sobstvennykh imen $v$ poemakh M. Yu. Lermontova. [Onomasticon in M. Yu. Lermontov's poems]. Surgut, Surgut State Pedagogical University Press, 2006. 88 p. (In Russ.)

Idiolektnyy onomastikon sibirskogo starozhila [Idiolectal onomasticon of the Siberian old resident]. Comp. by E. V. Ivantsova, E. A. Berestov, ed. by E. V. Ivantsova. Tomsk, Tomsk State University Press, 2015. 308 p. (In Russ.)

Ivantsova E. V. Idiolektnyy slovar' sravneniy sibirskogo starozhila [The Idiolectal Comparison Dictionary of the Siberian Old Resident]. Tomsk, Tomsk State University Press, 2005. $162 \mathrm{p}$. (In Russ.)

Ivantsova E. V. Idiolektnyy slovar' pretsedentnykh tekstov sibirskogo starozhila [The Idiolectal Precedent Texts Dictionary of the Siberian Old Resident]. Tomsk, Tomsk State University Press, 2016. 132 p. (In Russ.)

Obukhova E. S. Onomastika tvorchestva A. S. Pushkina peterburgskogo perioda (18171820): slovar'. [Onomastics of Pushkin's works of St. Petersburg's period (1817-1820): dictionary]. Voronezh, Istoki Publ., 2009. 168 p. (In Russ.)

Polnyy slovar' dialektnoy yazykovoy lichnosti [The Complete Dictionary of a Dialect Language Personality]. Ed. by E. V. Ivantsova. Tomsk, Tomsk State University Press, 2006, vol. 1. A-Z. 358 p.; 2007. vol. 2. I-O. 338 p.; 2009. vol. 3. P-R. 324 p.; 2012. vol. 4. S-Ya. 366 p. (In Russ.)

Slovar' yazyka russkikh proizvedeniy Shevchen$k o: v 2 t$. [The Dictionary of Language of Russian Literary Works by Shevchenko: in 2 vols.]. Ed. by V. M. Britsyn et al. Kiev, Naukovadumka Publ., 1985. (In Russ.) 


\section{VERSHININA FROM VERSHININO}

\section{Tatiana A. Sirotkina}

Associate Professor in the Department of Philological Education and Journalism

Surgut State Pedagogical University

10/2, 50 let VLKSM st., Surgut, 628417, Russian Federation. sirotkina71@mail.ru

SPIN-code: 7901-7167

ORCID: http://orcid.org/0000-0003-3494-0968

ResearcherID: D-5802-2018

Submitted 15.02.2018

The review presents one of new lexicographic publications by Tomsk linguistic scholars - Idiolectal Onomasticon of the Siberian Old Resident (compilers E. V. Ivantsova, E. A. Berestova; edited by E. V. Ivantsova. - Tomsk, Tomsk University Press, 2015. - 308 p.). Onomasticon of an ordinary native speaker of a language has not yet been the subject of a dictionary description, so the dictionary created by the linguists of the Tomsk linguistic school fills this lexical gap, establishing the tradition of recording different types of proper names functioning in the speech of a dialect speaker in a separate publication. The review considers the basic principles of constructing this dictionary. Following the tradition of the Complete Dictionary of the Dialectal Language Personality, the onomastic dictionary is built according to the same methodological principles: the focus on the fullest possible reflection of the language personality's lexicon, the orientation to a multidimensional description of lexical units, the principle of objectification of the features of the native speaker's language personality in the dictionary, and the principle of "soft" presentation of borderline phenomena with simultaneous referring of disputed or related cases to different classes. The review also deals with the illustrative material, which is of special value for readers, being a "three-dimensional encyclopedia" of life of the Russian village, its everyday routine and holidays. In the dictionary, there are also noteworthy statements, marked with a special sign, that contain manifestations of the speaker's metalingual reflection in relation to proper names. In such examples the object of comprehension is the form, semantics or functioning of the proper name in one's own or another's speech: its euphony / cacophony, its unusualness, inconsistency with the official naming, the presence of variant designations, the preferential use of one or another form of name, the naming motive, the connotation of the onym, the frequency, compliance / non-compliance with the norms of usage, etc. Based on the description of this lexicographic publication, a conclusion is drawn on the prospects of creating similar dictionaries on the dialect material of other territories of Russia.

Key words: idiolectal onomasticon; lexicography; Tomsk linguistic school; dictionary; onym. 